\title{
University of Waterloo
}

Civil Engineering

CIV E 596 - CONSTRUCTION MANAGEMENT

Course Outline

Instructor: Tarek M. Hegazy, CPH 2369C, ext: 32174, Email: tarek@uwaterloo.ca

\section{Course web site: www.civil.uwaterloo/tarek}

\section{Objectives:}

This course focuses on the successful management of construction projects within budget, deadlines, and resource limits. Students will learn the basics of cost estimating, scheduling,

bidding, and project control. The course focuses on the use of computer tools to train students on:

- Project delivery approaches and contract types

- Detailed cost estimation

- Planning and Scheduling

- Sharing multi-project resources

- Scheduling of Repetitive Projects (Infrastructure)

- Resource-constrained scheduling \& Resource leveling

- Time-Cost Trade-off Analysis

- Cash flow analysis

- Project control techniques

- Case Studies of Successful Projects

Suggested Textbook: Hegazy 2002, "Computer-Based Construction Project Management," Prentice Hall.

\section{References on Project Management:}

- Books on Project Management and Construction Management;

- Trade magazines (e.g., ENR);

- International journals such as the Journal of Construction Eng. and Management (ASCE) and the Journal of Computing in Civil Eng. (ASCE);

- Databases such as "current contents" and "compendex";

- International organizations such as Project Management Institute (PMI) and American Association of Cost Engineers (AACE);

- A lot of computer software programs;

- Internet search;

- Government publications such as statistics Canada, etc. 


\title{
CIVE 596 - Course Notes Based on \\ Computer-Based Construction Project Management
}

\author{
(c) Tarek Hegazy, Prentice Hall 2002
}

\section{CHAPTER 1: CONSTRUCTION PROJECT INITIATION}

From studying this chapter, you will be introduced to:

- The unique characteristics and challenges of the construction industry

- The life-cycle phases of projects

- The various decisions involved in initiating a project: project delivery methods; contract types; and contractual relations among project participants

- $\quad$ The competitive bidding process for project acquisition

- Recent trends in contract strategies

\subsection{Introduction}

A construction project is defined as a planned undertaking to construct a facility or group facilities. The principal participants in construction projects are the owner, the architect/engineer, the consultant, the general contractor, and the subcontractors. Usually, there are many ways in which some or all of the participants join their efforts in a project. A suitable arrangement of these participants depends on the nature of the project, the size and strength of each participant, and the project objectives and constraints. It is important therefore to understand the environment in which a construction project is initiated so that to clearly define the roles and responsibilities of the various participants and to bring the project to a success with respect to all of them. This chapter provides the background material regarding the organizational aspects of selecting the project participants, the contract type, and the project delivery approach that suit the environment of a project under consideration.

\subsection{Construction: A Magnificent Creativity}

Since the beginning of time, humans have been fascinated by large scale objects in nature such as mountains, landscape, and the endless oceans. With the sophistication of the humans along the years, some groups began to build large-size monuments of their own to glorify their civilization. The great pyramids of Giza are early examples of these monuments. Undoubtedly, the effort spent on building such huge monuments is a witness to the human ability to make creative and challenging construction. The impact of such large structures on human development has been tremendous on all fronts including social, economic, and cultural.

In recent history, the human fascination with developing large scale structures remains unchanged. The twentieth century has been marked by its far leap in terms of technology, materials, and human sophistication. No wonder it is the greatest century in which humans have developed so many structures of unique scale and creativity that impacted the lives of almost all humans. This century has also witnessed a rapid pace of developments on science and technology made by so many people in different places on our planet that is currently becoming a one village.

\subsection{Need for Scientific Project Management in Construction}

The construction industry is the largest industry in North America and worldwide. Although products are made, the construction industry is more of a service than a manufacturing industry. In Canada and the United States, investments in the construction industry amount to about $10 \%$ of the total investments in all industries. Growth in this industry in fact is an indicator of the economic conditions of a country. This is because the industry cuts across a large number of trades that consume a wide employment circle of labor. Construction also feeds and interacts with the manufacturing industry, which exports a large portion of its products to the construction industry. 
In the construction industry, most projects exhibit cost overruns, time extensions, and conflicts among parties. The reasons for the widespread of these problems can generally be attributed to three main factors (Fig. 1.1): (1) the unique and highly uncertain nature of construction projects; (2) the fragmented and highly competitive nature of the construction industry; and (3) the ever increasing challenges facing the industry as a whole. In view of these increasing challenges, efficient management becomes a key to the success of any construction organization.

A scientific approach to construction project management can help construction participants in many ways, including:

- $\quad$ Cope with the increasing complexity of modern projects;

- Utilize resources (4 M's) efficiently: Manpower, Materials, Machinery, and Money;

- Meet fiscal requirements and deadlines;

- Communicate effectively among the participants and avoid adverse relations;

- Improve construction quality and safety record;

- Achieve higher productivity; and

- Document and utilize past experience to improve future construction.

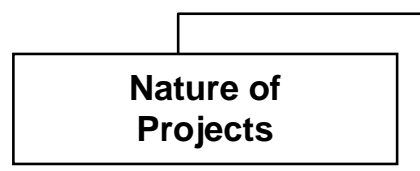

- Projects are unique and unrepeatable;

- Projects are temporary;

- Projects are constrained by time, money, \& quality;

- Projects involve many conflicting parties; and

- Many decisions are made based solely on experience.

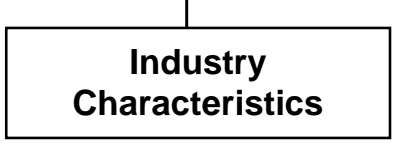

- Extremely fragmented, with many small specialties involved;

- Intense competition and high failure rates;

- Rapidly affected by recessions;

- Little R\&D expenditures;

- Confidentiality and lack of information sharing; and

- Slow to adopt new technologies.

\section{Increasing Challenges}

- Global market competition;

- Increasing regulations (e.g., environmental and safety);

- New advances in materials and equipment;

- Tight budget, less time, yet better quality is demanded;

- Rising costs; and

- Lack of skilled resources.

\section{Fig. 1.1: Reasons for Poor Performance in Construction}

In order for these benefits to be materialized, construction project management as a discipline, has as its objective the control of three main aspects of construction: Time (T); Quality (Q); and Money (M). The (TQM) acronym is also in rhythm with the principles of "Total Quality Management" (Fig. 1.2) which is a wide umbrella for quality in business and manufacturing. The specific discipline of Construction project management, therefore, involves a wide spectrum of techniques and approaches that are discussed in this book and attempt to achieve its objectives through systematic application of: (1) Contract Management; (2) Information Management; (3) Cost Management; (4) Time Management; (5) Resource Management; (6) Financial Management; and (7) Execution Management.

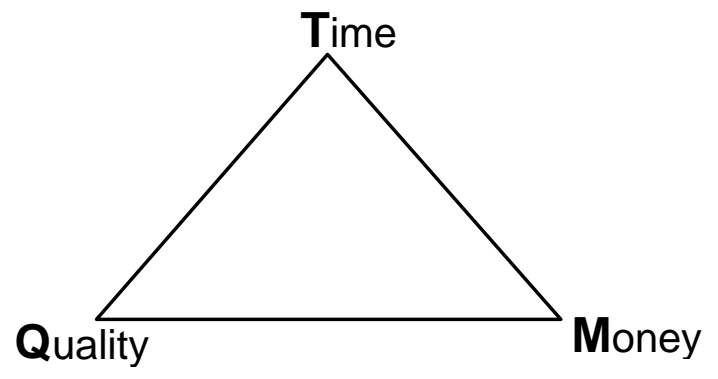

Fig. 1.2: Total Quality Management Objectives 


\subsection{Construction Project Participants}

Owner: The owner (also referred to as the Client) is the individual or organization for whom a facility or project is to be built or a service furnished under a contract. The owner, whether public or private, owns and finances the facility or project. Public owners are public bodies of some kind ranging from agencies of the federal government down through the state, county, and municipal entities including boards, commissions, and authorities. Most Public projects or facilities are built for public use and not sold to others. Private owners may be individuals, partnerships, corporations, or various combinations thereof.

Architect: An Architect is an individual who plans, programs, and designs buildings and their associated landscaping. Sometimes the architect also provides the aesthetics of the whole envelope or concept of the whole project. Since most architects have only limited capabilities in structural, electrical, and other specialized design, they mostly rely on consulting engineers for such work.

Architect/Engineer (A/E): The architect/engineer (also known as the design professional) is part of the business firm that employees both architects and engineers and has the capability to do complete design work. The A/E firm also may have the capability to perform construction management services.

Construction Manager: The construction manager is a specialized firm or organization which furnishes the administrative and management services. The construction manager is responsible for design coordination, liaison in the proper selection of materials and methods, contracts preparation, and cost/schedule/quality control.

Engineer: usually refers to an individual and/or a firm engaged in specialized design or other work associated with design or construction. Design engineers are usually classified as civil, electrical, mechanical, environmental, and so on, depending upon their specialty. There are also scheduling, estimating, cost, and construction engineers who originated from any of the basic engineering disciplines.

Engineering-Construction Firm: an organization that combines both architect/engineering and construction contracting. The firm has the capability of executing a complete design-build sequence, or any portion of it. Sometimes this firm does the procurement of the equipment and materials needed to construct the project.

General Contractor (G.C.): The general contractor (also known as the Prime Contractor) is the business firm that is under contract to the owner for the construction of the project, or for a major portion of the project. Subcontractors are frequently engaged, although the prime contractor retains the responsibility for the satisfactory performance of these subcontractors.

Project Manager: The project manager is the individual charged with the overall coordination of all the facets of a construction program: planning, design, procurement, and construction, for the owner.

Subcontractor: A subcontractor is under contract to another contractor, as opposed to an owner, to perform a portion on the contractor's work. A general contractor who is under contract with an owner may engage subcontractors for portions of the project, the type and amount depending on the nature of the project and the contractor's own organization. These subcontractors, in turn, may engage other subcontractors. Thus, there can be several levels of subcontracting to a general contractor.

Specialty Contractor: This contractor performs only specialized construction, like plumbing, electrical, and painting, either as a subcontractor or as a prime contractor.

\subsection{Types of Construction}

There is no universal agreement on the categories or types of construction and their inclusive elements. One simple classification is shown in Fig. 1.3 with the three main categories of residential buildings, non-residential buildings, and non-building construction. The numbers shown in the figure are approximate and generally apply to the United States and Canada.

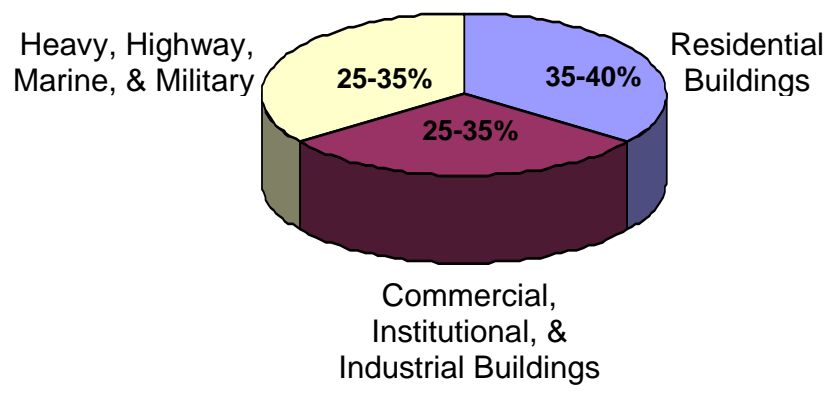

Fig. 1.3 Simple Classification of Construction Types 


\subsection{Life Cycle Stages of Projects}

The development of a construction project, from its initiation into its operation, may be divided into the following consecutive stages, as shown in Fig. 1.4:

Concept Stage: When the need to build a new project is identified, the process of appraising various alternatives commences. This study, which is known as feasibility study, can in some cases expand several years, particularly if environmental assessments need to be made. The study determines whether the project is truly viable and which are the various alternatives for carrying it out will be best. The master schedule using approximate durations of various operations is then prepared in order that the owner may know how long and how much it would take to reach the objective. The concept stage, in fact, is one of the major steps in a project life-cycle as it has the largest impact on cost and performance, as shown in Fig. 1.4.

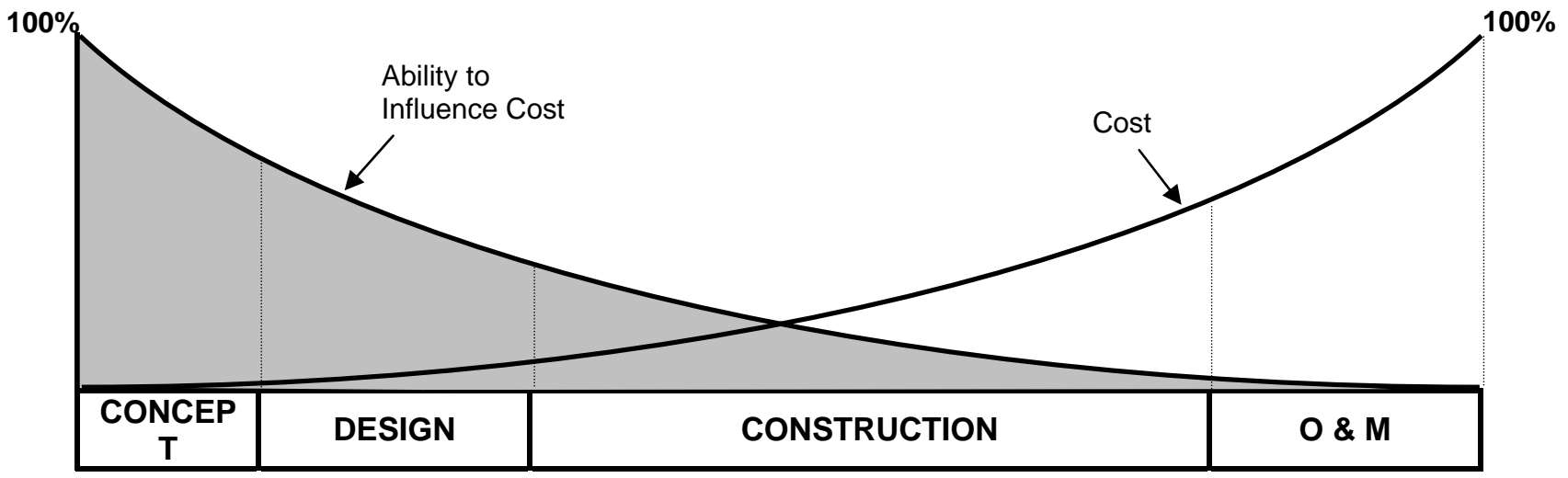

Fig. 1.4: Project Life-Cycle Phases

Design Stage: In this stage, decisions are taken concerning the sizes and types of structures required and the conceptual design is prepared. This involves the preparation of outline drawings and details of all services.

Upon owner approval of the conceptual design, detailed design, other steps are carried out to prepare detailed design, prepare specification and quantities of work, prepare tender documents, and implement the project contract strategy to procure of bids and award the construction contract.

Construction Stage: The chosen project completion date will determine the overlap between the design and construction stages. The general contractor will carry out site construction. A mechanical and or electrical installation may be subcontracted under the supervision of the general contractor. The consultants will be deployed for contract administration and construction supervision. The contractor would seek the most efficient use of his resources using construction management techniques.Commissioning is then made and performance tests conducted, leading to project acceptance.

Operation \& Maintenance ( $0 \&$ \&): The operational maintenance of the project may be carried out by the owner's own employees. Project review may be required for future interests. Demolition at end of service life.






\subsection{Project Contract Strategy}

At the early stage of a project and once a project manager is selected, the main issue that faces the owner is to decide on the contract strategy that best suits the project objectives. Contract strategy means selecting organizational and contractual policies required for the execution of a specific project. The development of the contract strategy comprises a complete assessment of the choices available for the management of design and construction to maximize the likelihood of achieving project objectives.

A road map to selecting a proper contract strategy for a project is illustrated in Fig. 1.5, involving five key decisions related to:

1. Setting the project objectives and constraints

2. Selecting a proper project delivery method

3. Selecting a proper design/construction interaction scheme

4. Selecting a proper contract form / type

5. Contract administration practices

Details on these five broad aspects are given in the following subsections.

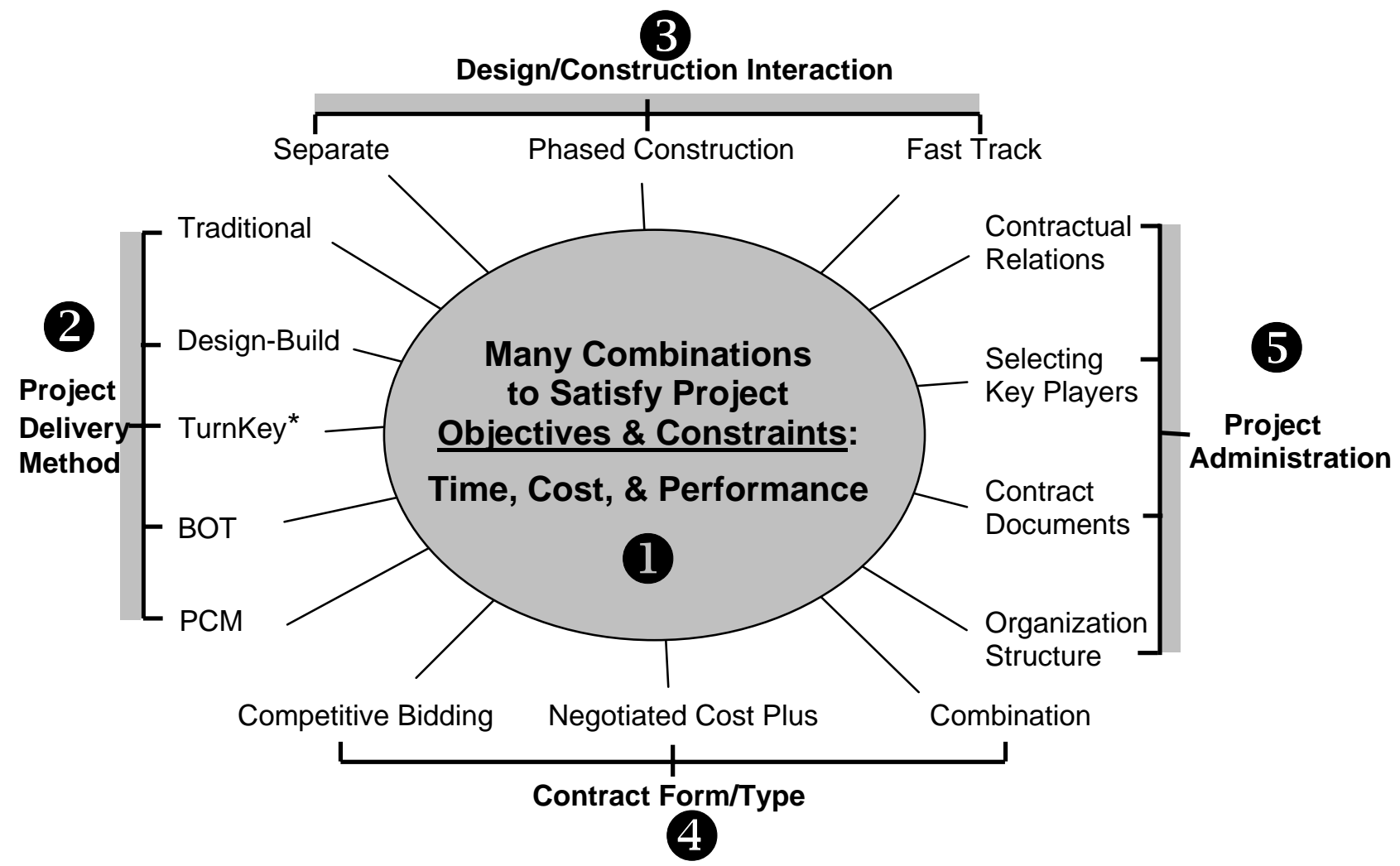

* Abbreviations are explained in detail in the following sections

Fig. 1.5: Key Considerations in a Contracting Strategy

As shown in Fig. 1.5, there exist a large number of possibilities for a contracting strategy. Innovative strategies can achieve various benefits, including: Shortening project duration by overlapping design and construction; providing flexibility for changes during construction; creating more designer/contractor teamwork to reduce adverse relationships; allowing a contractor to participate in the design process, thus augmenting the designer's construction experience; providing incentives for the contractor to save the owner money; and providing alternative financing methods. 


\subsubsection{Project Objectives and Constraints}

A summary of various project objectives and constraints are as follows:

Time objective: There may be a need for an early start to the construction phase for political reasons and/or a need for minimum project duration to maximize economic return. If this objective is top ranked by the owner, the contracting strategies that allow speedy project delivery, such as overlapping design and construction, may become desirable.

Cost objective: There may be a need for minimum project cost to ensure adequate economic return, a need for minimum total cost incorporating operation and maintenance costs, or a need to observe a maximum limit on monthly expenditure. The selected contracting strategy, therefore, should be flexible to the owner's requirement, while also maintaining the other objectives.

Performance objective: An appropriate functional performance of each component in a project can be defined as the minimum acceptable to the owner and to society. To attain this objective, a "Value Engineering" program may be adopted by the project management team at the design stage to reevaluate the design components, thus introducing changes that save cost without sacrificing performance. If this objective is top ranked by the owner, a contracting strategy that accommodates changes and to a teamwork approach may become desirable.

Project constraints: All construction projects will have constraints that influence the achievement of project objectives. These constraints should therefore be considered when choosing an appropriate contract strategy. Some of the project constraints are:

- Conditions of contract

- Method of tender

- Project size and duration

- Project location

- Relationship to other projects

- Possession of land

- Number of work packages

\begin{tabular}{|l|l} 
- Target dates of the project & - Access to the site \\
- Possibility of design changes & - Number of contractors willing to \\
- Availability of construction resources & tender \\
- Freedom to choose designers and & - Inflation \\
contractors & - Exchange-rate \\
- Adequacy of site investigation & - Union Regulations \\
- Seasonal working &
\end{tabular}

\subsubsection{Project Delivery Methods}

The choice of a project delivery method should be related to project objectives and constraints, and also to the scope or the portion of the project tasks- design, construction, and finance- that is assigned to the contractor. The various project delivery methods are summarized as follows:

Traditional Approach: This is the most common approach in civil engineering projects in which the design has to be completed before construction can start. Design and construction are usually performed by two different parties who interact directly and separately with the owner. This approach takes two common forms:

a) Owner direct force:

b) General Contractor (G.C.):

Table 1.1: Pros and Cons of the Traditional Approach

\begin{tabular}{l|l}
\hline \multicolumn{1}{c|}{ Advantages } & \multicolumn{1}{c}{ Disadvantages } \\
\hline - Price competition & - Long time \\
- Total cost is known before construction & $\begin{array}{l}\text { - Design does not benefit from construction } \\
\text { experience }\end{array}$ \\
starts & Well documented approach used in most \\
government projects done for public works & $\begin{array}{l}\text { Conflicts between owner \& G.C. and } \\
\text { between A/E \& G.C. } \\
\text { - Changes may lead to disputes and claims }\end{array}$ \\
\end{tabular}

Therefore, this method is fine in many cases where the project is clearly definable, design is completed, time need not be shortened, and changes are unlikely to occur during construction. 
Design-Build: In this approach, a single organization is responsible for performing both design and construction and, in some cases, providing a certain "know-how" for the project.

Table 1.2: Pros and Cons of the Design-Build Approach

\begin{tabular}{l|l}
\hline \multicolumn{1}{c|}{ Advantages } & \multicolumn{1}{c}{ Disadvantages } \\
\hline - One contract that may include know-how & $\begin{array}{l}\text { - Cost may not be known until the end of } \\
\text { design }\end{array}$ \\
- Minimum owner involvement & \\
- Time can be reduced if the design-build & - High risk to contractor and more cost to \\
company overlaps design and construction & owner \\
- Possible coordination between design and & $\begin{array}{l}\text { - Design-Build company may reduce quality } \\
\text { construction }\end{array}$ \\
- Easier implementation of changes & - Due to minimal owner involvement, result \\
- Less adversary relationships & may not be to his satisfaction
\end{tabular}

The use of this approach, therefore, should be considered when contractors offer specialized design/construction/know-how expertise or when design is strongly influenced by the method of construction.

Turnkey: This approach is similar to the design-build approach but with the organization being responsible for performing both design, construction, know-how (if any), and project financing. Owner payment is then made at the completion (when the contractor turns over the "key"). An example is franchise projects in which a new branch of a restaurant chain needs to maintain the same design, construction quality, and food service quality.

Build-Operate-Transfer (BOT): In this approach, a business entity is responsible for performing the design, construction, long-term financing, and temporary operation of the project. At the end of the operation period, which can be many years, operation of the project is transferred to the owner. This approach has been extensively used in recent years and is expected to continue. An example of its use is in express routes and turnpikes. A consortium of companies shares the cost (design, construction, financing, operation, and maintenance) and the profits gained from user fees, for a stipulated number of years. Afterwards, the project returns to the government to become publicly owned. This approach has also been used extensively in large infrastructure projects financed by the World Bank in parts of the world that cannot afford the high investment cost of such projects.

Professional Construction Management (PCM): In this approach, the owner appoints a PCM organization (also known as Construction Management organization) to manage and coordinate the design and construction phases of a project using a Teamwork approach. The design may be provided by specialist design firms and in some cases by the PCM organization. With high level of coordination between the participants, innovative approaches of overlapping design and construction (i.e., fast tracking) can be adopted. The PCM organization aims at holding a friendly position similar to that of the consultants in the traditional approach.

The services offered by the PCM organization overlap those traditionally performed by the architect, the engineer, and the contractor. This may include: management and programming of design; cost forecasting and financial arrangements; preparation of tender documents; tender analysis and selection of contractors; selection of methods of construction; recommendations on construction economics; planning and scheduling construction works; materials procurement and delivery expedition; provision for site security, cleanup, and temporary utilities; supervision of control of construction contractors; construction quality assurance; cost control; costing of variations and assessment of claims; and certification of interim and final payments to contractors.

Table 1.3: Pros and Cons of the PCM Approach

\begin{tabular}{l|ll}
\hline \multicolumn{2}{c|}{ Advantages } & \multicolumn{1}{c}{ Disadvantages } \\
\hline - Utilization of construction skills at all & - $\begin{array}{l}\text { Higher owner involvement } \\
\text { responsibilities }\end{array}$ \\
stages with no conflict among participants & \multicolumn{1}{l}{ and } & \\
- Independent evaluation of cost and & - Need skilled construction managers & \\
schedule to the best owner interest & - PCM fees (up to 4\%) \\
- Time could be much less & & \\
- Principals such as "Value Engineering" & & \\
could be applied in all phases & & \\
\hline
\end{tabular}

The use of PCM approach, therefore, should be considered when there is a need for time saving, flexibility for design changes is required, and owner has insufficient management resources. 


\subsubsection{Design/Construction Interaction}

In conjunction with decisions related to a suitable project delivery approach, the owner generally has three basic choices for the management of design and construction, as illustrated in Fig. 1.6:

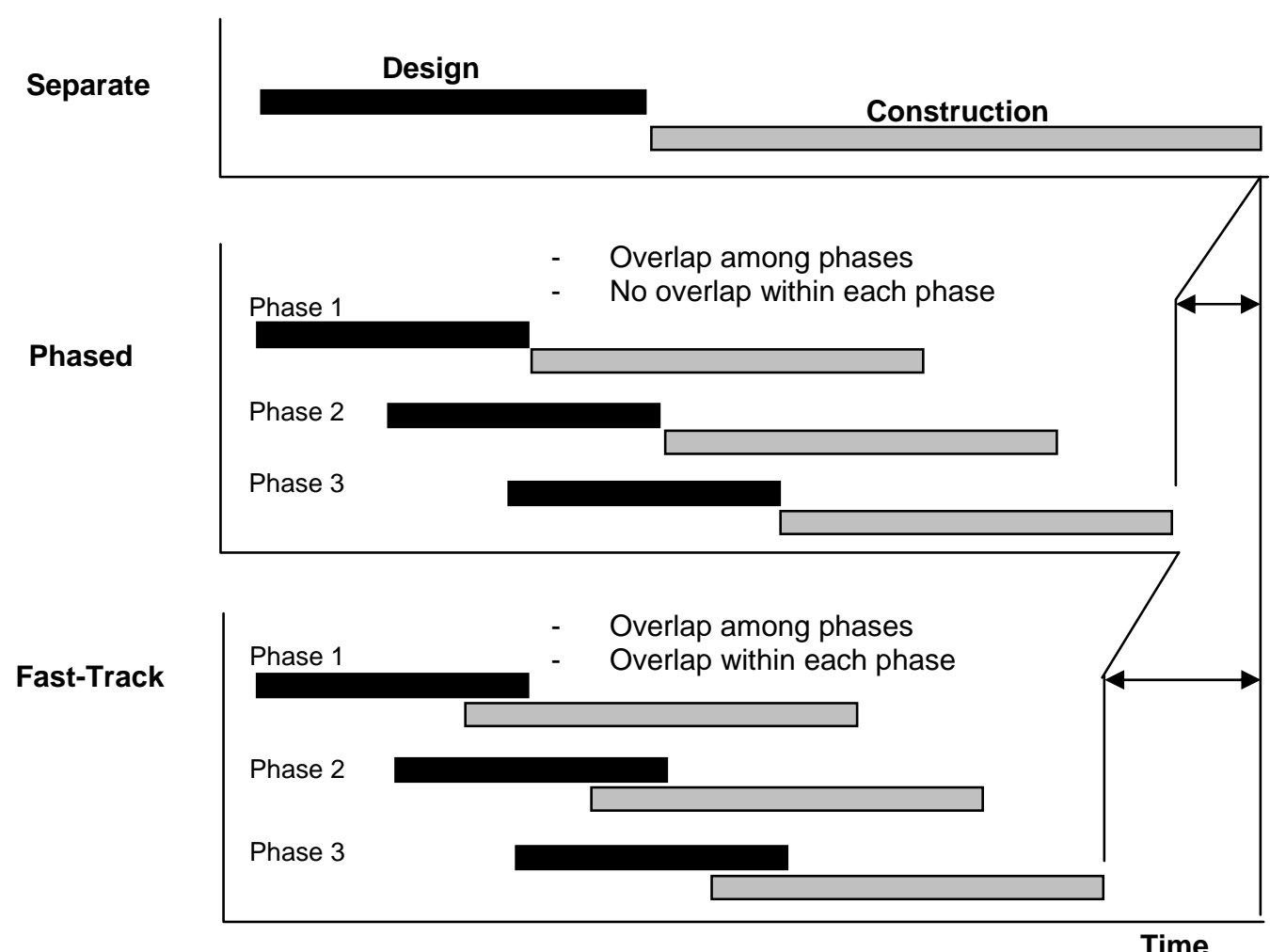

Fig. 1.6: Different Design/Construction Interaction Schemes

Phased and fast-track approaches certainly require high levels of coordination and management to bring them to success. A PCM project delivery approach, therefore, may become desirable if time saving is a top ranked objective to the owner. In general, therefore, decisions regarding the level of design/construction interaction required for a project can be facilitated by considering the following aspects:

- Extent to which construction is to be separated from or integrated with design;

- Size and nature of the work packages within the project;

- Appropriate number of design teams to suit the nature of the work;

- Selection of the design teams from in-house resources or external consultants;

- Process of supervision of construction; and

- Restrictions on using a combination of contracting strategies within the project.

\subsubsection{Construction Contract Form/Type}

Construction contracts can be broadly grouped into two categories: (1) competitive biding contracts; and (2) negotiated cost-plus contracts. Specific contract types are classified according to the method of payment to the contractor. For example, the two common forms of competitive bidding contracts, lump sum and unit price, explicitly specify the method by which the contractor's submitted price is paid to him. Similarly, the various types of negotiated cost-plus contracts differ in the way in which the contractor is reimbursed for his cost (rather than price). The various contract forms are illustrated in Fig. 1.7. A discussion of the process of competitive bidding, as the main process for selecting contractors, is provided next. The three basic factors that favor the use of a particular type of contract are: 
- The need to provide an adequate incentive for efficient performance;

- The ability to introduce changes during construction; and

- The allocation of risks between owner and contractor and the cost implication.

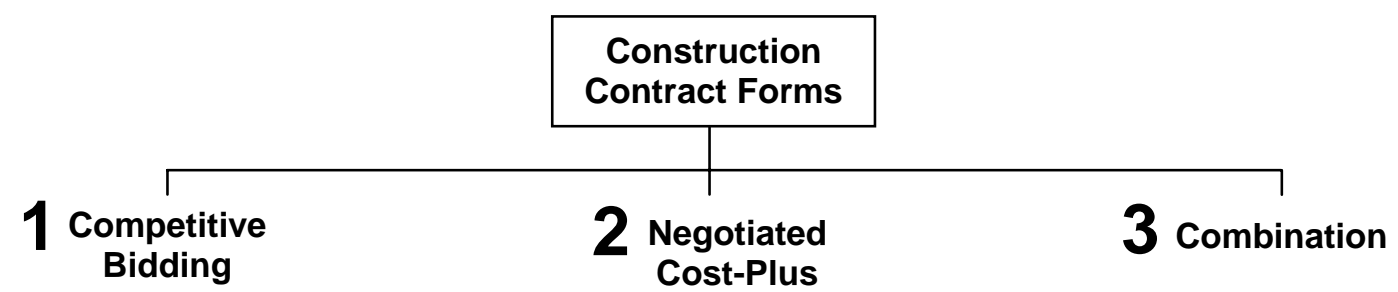

Two Main Types:

- Lump Sum (Buildings)

- Unit Price (Heavy)

\section{Competitive Bidding Contracts:}

a) Lump Sum: A single tender price is given to the contractor for the completion of a specified work to the satisfaction of the owner. Payment may be staged at intervals of time, with the completion of milestones. Since the contractor is committed to a fixed price, this type of contract has been very limited flexibility for design changes. In addition, the tender price, expectedly, includes a high level of financing and high undisclosed risk contingency. One benefit to the owner, however, is that the contract final price is known at tender. But, an important risk to the owner is when not receiving competitive bids from considerable contractors who avoid higher risks on lump sum contract. Generally, this contract is appropriate when the work is defined in detail, limited variation is needed, and level of risk is low and quantifiable. It can be used for traditional, design-build, and turnkey projects. Lump sum contracts are also suitable for building projects since many items of the work in which detailed quantities of work cannot be estimated, such as electrical work.

b) Unit Price: In this contract type, bidders enter rates against the estimated quantities of work. The quantities are re-measured during the course of the contract, valued at the tendered rates, and contract price adjusted according. The rates include risk contingency. Payment is made monthly for all quantities of work completed during the month. The contract offers a facility for the owner to introduce variations in the work defined in the tender documents. The contractor can claim additional payment for any changes in the work content of the contract, but this often leads to disputes and disagreements. One variation of this type is called "Schedule of Rates" contract which contains inaccurate quantities of work, possibly with upper and lower probable limits. Therefore, instead of submitting one total rate for each item of work, contractors submit separate rates for the labor hour, plant hour, and materials rates. The contract price is then devised by measuring the man-hours, plant hours, and quantities of materials actually consumed, and then pricing them at the tendered rates. Unit price contracts are best suited for heavy civil and repetitive work in which work quantities can be easily estimated from design documents.

\section{Negotiated Cost-Plus Contracts:}

In this category of contract types, project risks are high and can discourage contractors from being committed to a lump sum or fixed unit prices. Therefore, the owner shares the project risks by reimbursing the contractor for 
his actual costs plus a specified fee for head office overheads and profit. To allow for that, the contractor makes all his accounts available for inspection by the owner or by some agreed-upon third party. This category of contracts offers a high level of flexibility for design changes. The contractor is usually appointed early in the project and he is encouraged to propose design changes in the context of value engineering. The final price, thus, depends on the changes and the extent to which risks materialize.

Some of the common types of cost-plus contracts, classified by the method of payment to the contractor, are:

a) Cost + Fixed Percentage: While this contract is simple to administer, it has no incentive for the contractor to save owner's money or time. Also, problems may occur if the contractor engages his resources in other projects and delays the work.

b) Cost + Fixed Fee: The fee is a fixed amount of money. As such, the contractor's fee will not increase if costly changes are introduced. While the contractor may desire to finish the project earlier, he still has no incentive to save owner's money.

c) Cost + Fixed Fee + Profit Sharing: In addition to the reimbursement of actual costs plus a fixed fee, the contractor is paid a share of any cost saving that he introduces into the work.

d) Cost + Sliding Fee: The sliding fee is a fee that increases linearly with the amount of cost saving that the contractor introduces between the actual cost and a preset target cost, as shown in Fig. 1.8. The fee can also be reduced when the actual cost exceeds the target.

Fig. 1.8: Sliding Fee

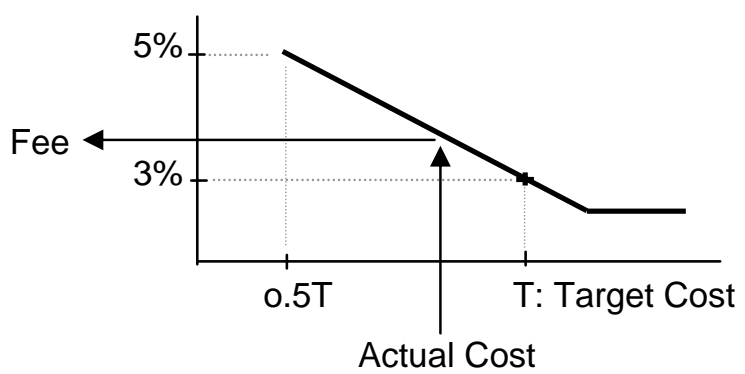

It is noted that the target tender should be realistic and the incentive must be sufficient to generate the desired motivation. Specific risks can be excluded from the tendered target cost and when these risks occur, the target cost is adjusted accordingly.

e) Cost + Guaranteed Maximum Price (GMP): The contractor's cost in this case is reimbursed with the contractor giving a cap on the total price not to exceed a pre-set value.

A brief summary of the level of risk exposed by each of the discussed contract forms is illustrated in Fig. 1.9. As shown in the figure, competitive bidding contracts (Lump Sum and Unit Price) are among the top risky contracts to contracts and thus present a challenge in estimating their cost and schedule at the bidding stage and before a commitment is made.

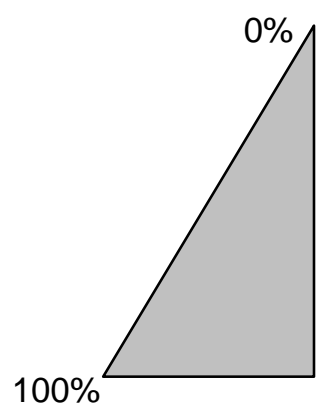

OWNER RISK
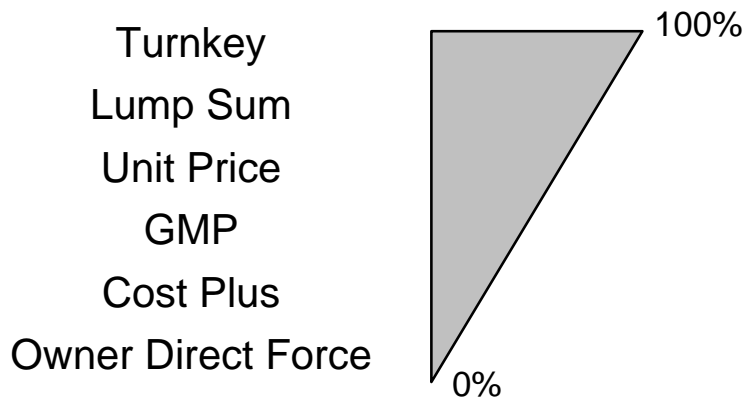

Fig. 1.9: Level of Risk Associated with Various Contracts 


\subsubsection{Project Administration Practices}

\section{Contractual Relationships}

Within each project delivery method, the contractual relationships among the project participants can take various arrangements and the owner needs to make a decision regarding the proper arrangement that suits the project and the parties involved. The two basic contractual relationships with an owner are: agent relationship, referred to as (A); and non-agent relationship, referred to as (\$). The agent relationship is a contract, such as that between the owner and an A/E firm. In this case, the agent organization performs some service (e.g., design), in addition to, possibly, representing the owner in front of other parties (e.g., supervision over the contractor). The non-agent relationship, on the other hand, is a regular legally binding contract to perform a service, such as the contract between the owner and the contractor. The different contractual relationships associated with various project delivery methods are illustrated in Figs. 1.10 and 1.11.

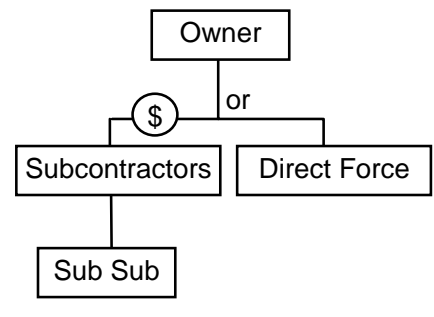

Owner's Own Force

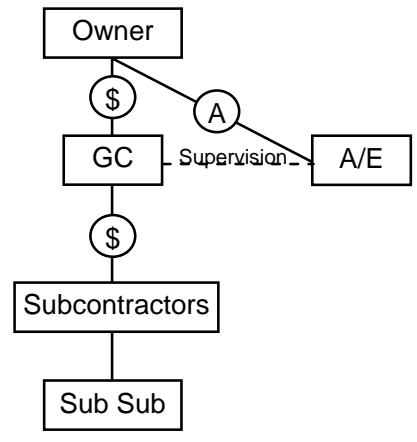

General Contractor

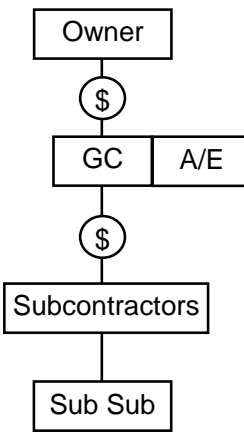

Design-Build and Turnkey

Fig. 1.10: Contractual Relations in Traditional and Design-Build Projects

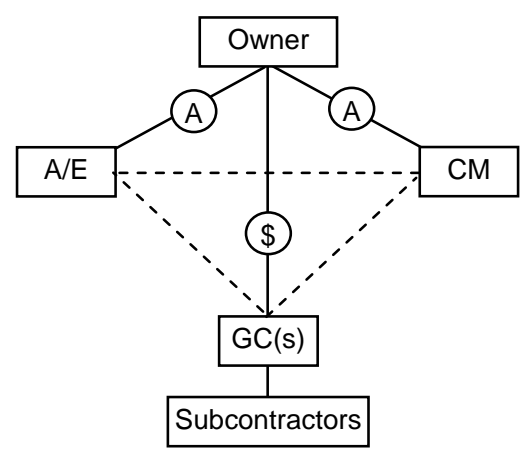

Agent CM



Contractor CM

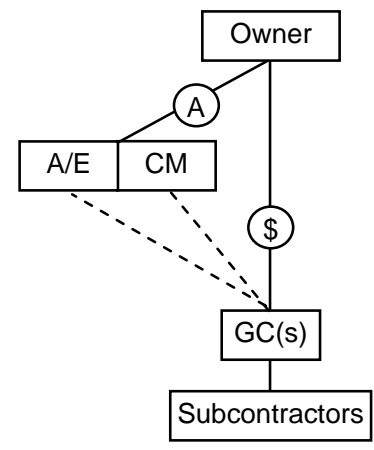

Design CM

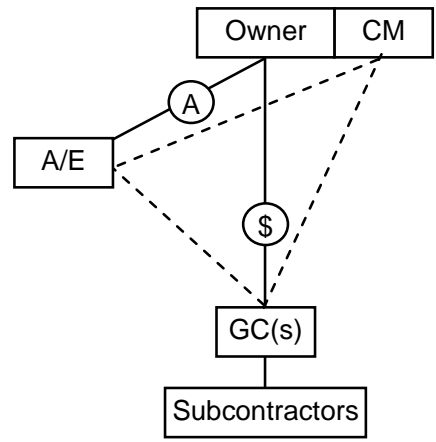

Owner CM

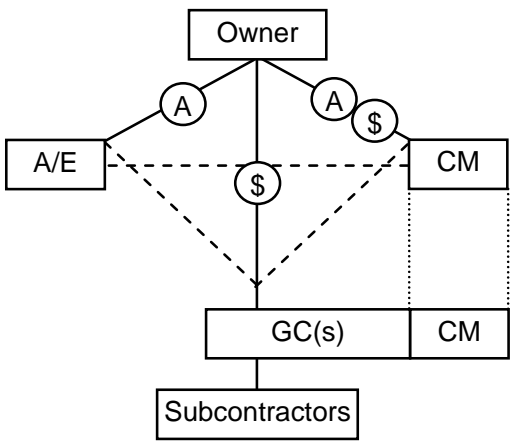

Constructor CM

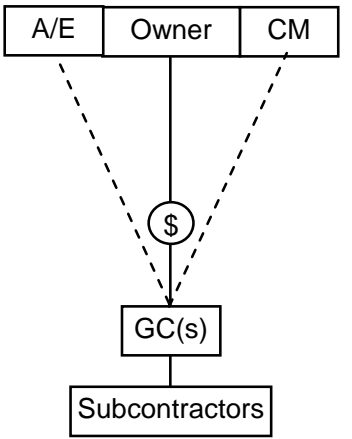

Owner/Design/CM

Fig. 1.11: Various Forms of Construction Management (CM) Contracts 


\section{Selecting the Key Player: The Contractor}

Selecting key personnel and organizations that will participate in a project is a major step for the owner and can mean the success or failure of a project. By large, the competitive bidding process has been the main vehicle for contractors to obtain jobs. The process is required by law for public projects, which has been the largest percentage of all projects, except in emergencies such as war or natural disasters. Under this process, a simple quantitative criteria is used to award the bid to the "lowest responsible bidder", thus potentially obtaining the lowest construction cost. The process, however, has its drawbacks, including: (1) overlooking important criteria such as contractor's experience and strength; (2) potentially causing construction delays and problems if the contractor bids below cost to win the job; and (3) contributing to adverse relationships between the owner and the contractor. The competitive bidding process encompasses three main steps (Fig. 1.12):

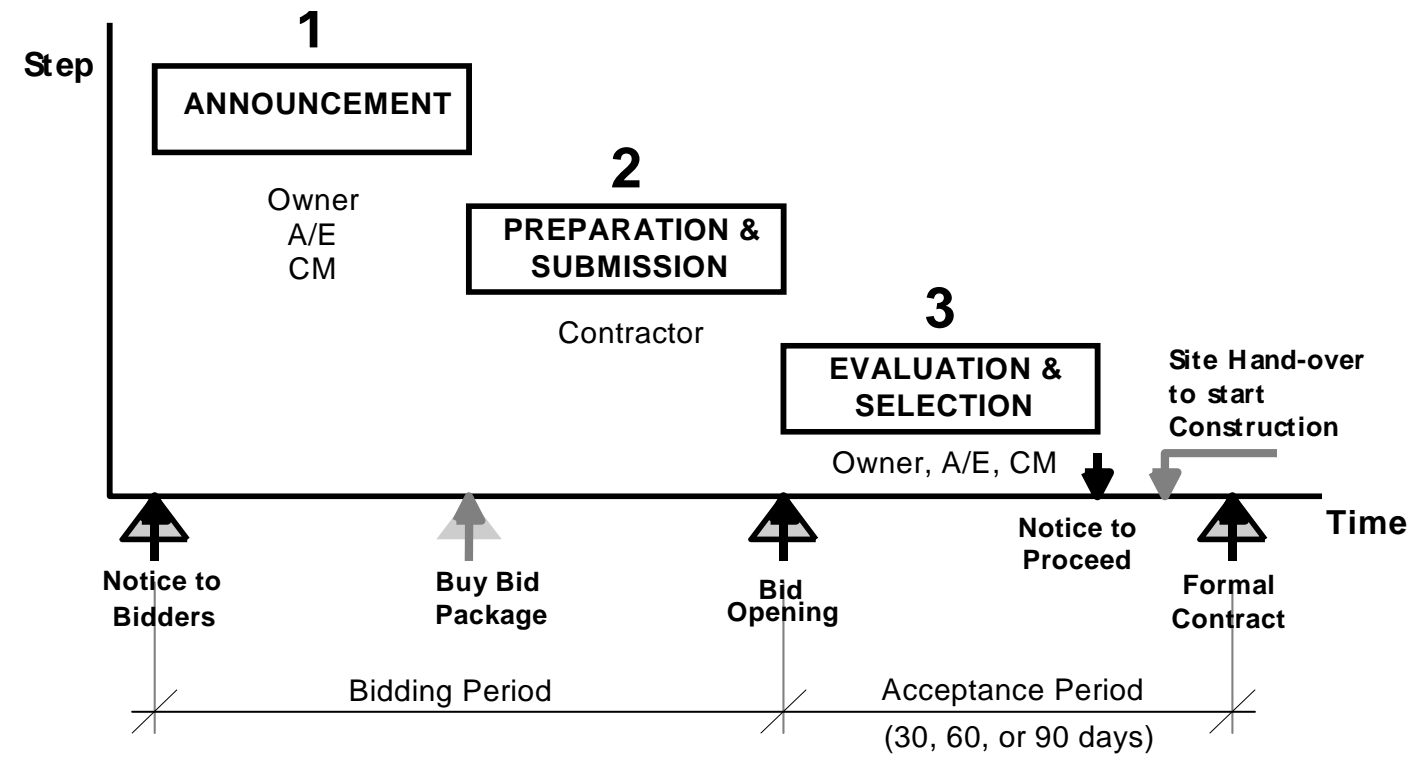

\begin{tabular}{l|l}
\hline Announcement & Announcement includes the following information: \\
& - Subject/scope of work, location, type of project; \\
& - Dates: purchase of bid package, bid submission, bid opening, etc; \\
& - Required pre-qualification documents; \\
& - Bid bond and its amount (0 to 10\%) to ensure seriousness; \\
& - Performance bond and its amount (e.g., 100\%) to ensure quality; \\
& - Price of bid package; and \\
- Conditions for acceptance/rejection.
\end{tabular}

Fig. 1.12: The Competitive Bidding Process 
To announce for a project, the owner should have the design completed and a bid package prepared with all design information. The owner then announces a general call for bidders or sends a limited invitation to a list of pre-qualified contractors. Through the limited invitation, the owner organization can reduce potential construction problems by avoiding unknown contractors who intentionally reduce their bids to win jobs, particularly if the project requires a certain experience. Owners, therefore, need to maintain a list of qualified contractors with whom they had successful experience or by advertising a call for pre-qualification.

\section{Contract documents}

Once the parties that will be involved in a project are identified, their legal binding is a set of contract documents. The main goals of the contract documents are to enable fair payment for the work done by the contractor, to facilitate evaluation of changes, and to set standards for quality control. Typical contract documents that are needed for this purpose are:

- Conditions of contract;

- Specifications;

- Working drawings;

- Priced bills of quantities or schedules of rates;

- Signed form of agreement which confirm the intent of the parties; and

- Contract minutes of correspondence.

The basis of a successful contract is the preparation of the conditions of contract to clearly define the responsibilities of the parties. These conditions form much of the legal basis of the contract on which any decision by the courts would be made. The interests of all parties to a construction contract would be best served if the contractor is required to carry only those risks that he can reasonably be expected to foresee at the time a bidding. This will be less costly to the owner and better suited to the efficiency of the construction industry.

Some of the legally binding aspects included in the conditions of contract are briefly discussed in this section. The contract period, liquidated damages, and incentives clearly defines that if the contractor fails to complete the works within the contract period, he will pay the liquidated damages. In case of early completion, the contractor is paid the incentive amount. A Retention amount is also an amount that is held back by the owner for each certificate of payment due to the contractor. Its value is about $5 \%$ to of each payment as insurance against defective work and to ensure the contractor has incentive to complete all aspects of work. The retention money is paid at the end of the contract. Maintenance period is usually specified as 52 weeks after the contract is completed, in which the contractor must remedy any defects that may appear in the work. Two types of Bonds are required from the contractor in the form of letters of guarantee given by an approved surety, a bank, or a company that agrees to discharge the legal duties of the contractor if he fails to do so. The bid bond ranges from 0 to $10 \%$ of the tender price to ensure that the bidder is serious and will maintained his offer when selected. The performance bond, on the other hand, is required from the selected contractor after award of the contract to ensure that he faithfully performs his obligations under the contract. This bond may be 5 to hundred percent of the total contract price. Conditions for a valid claim can also be specified in the conditions of contract. The contractor should read the conditions of contract to ascertain which category of claim is applicable. Construction managers are advised, immediately after the event that is likely to produce extra cost or delay, to negotiate with the owner the basis for the claim.

\section{Project Organization Structure}

At the early stage of project initiation, one important decision has to be made by owners best on how to tie the project to the owner's parent firm. To address this issue, we look at the major organizational forms commonly used to house projects and discuss some of the critical factors that might lead us to choose one form over the other. As shown in Fig. 1.13(a), the two extreme ways of organizing a project are the Functional and the Project organizations. In between these two extremes are various forms of Matrix (mixed) organization structures. With the full authority in the Functional structure with the functional managers, an urgent work that is needed for a specific project might be delayed if functional managers are busy with other projects. On the other hand, while the Project structure is more responsive to the needs of a construction project, it requires a lot of owner resources since each project has all the resources it needs. Also, the project structure is likely to exhibit a stressful work environment and anxiety as compared to the functional structure. The matrix structure, therefore, is a sort of trade-off that ensures efficient utilization of owner resources. The general form of a matrix 
organization is illustrated in Fig. 1.13(d). Among the various matrix variations, several studies have reported that Project-Matrix is most suited to the dynamic nature of construction projects. It's requirement of resources is not a purely project structure and as such does not require large amount of resources. However, the matrix structure has some potential problems that are a result of the fact that several project managers are competing to have the pool of technical experts under the various functional areas work on their projects before others. In some cases political problems may occur between various project managers. In other cases, there could be a doubt who is in command, the project manager or the functional manager. Careful assignment of the responsibilities in addition to proper management practices are, therefore, important issues for the success of owner organization.

\begin{tabular}{|c|c|c|}
\hline 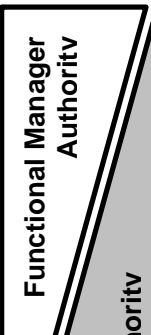 & $\begin{array}{c}\text { Function } \\
\text { Function - Matrix } \\
\text { Balanced Matrix }\end{array}$ & $\begin{array}{l}\text { Project is assigned to relevant } \\
\text { functional areas. } \\
\text { A PM limited authority coordinates } \\
\text { across different functional areas. } \\
\text { A PM shares responsibility and } \\
\text { authority with functional managers. }\end{array}$ \\
\hline 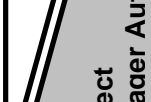 & Project - Matrix & $\begin{array}{l}\text { A PM is the prime authority. Funct- } \\
\text { ional personnel are used if needed. }\end{array}$ \\
\hline & Project & $\begin{array}{l}\text { A PM is in charge of a team of } \\
\text { personnel from functional areas. }\end{array}$ \\
\hline
\end{tabular}

(a) Comparison of Organization Structures

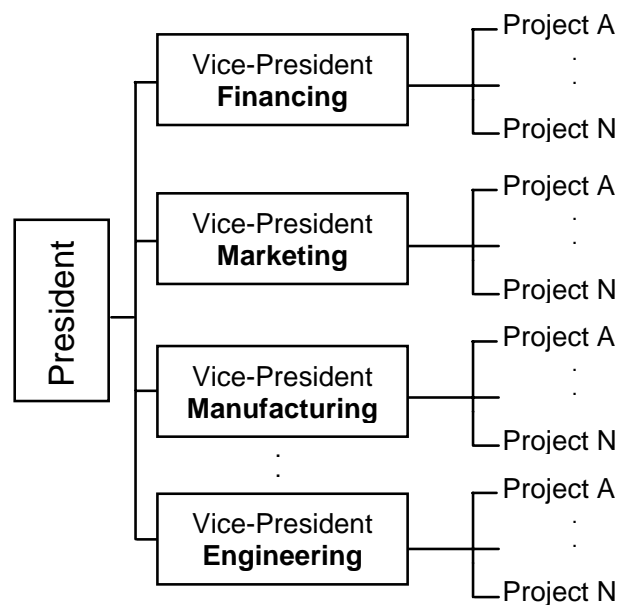

(b) Function Organization

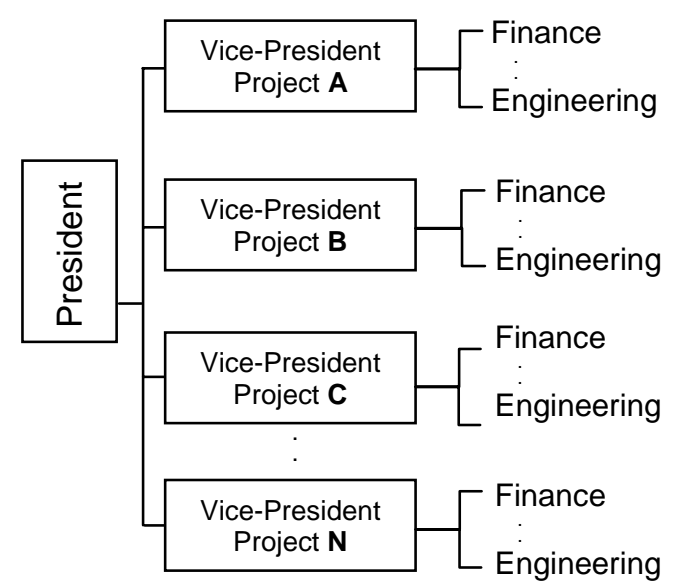

(c) Project Organization

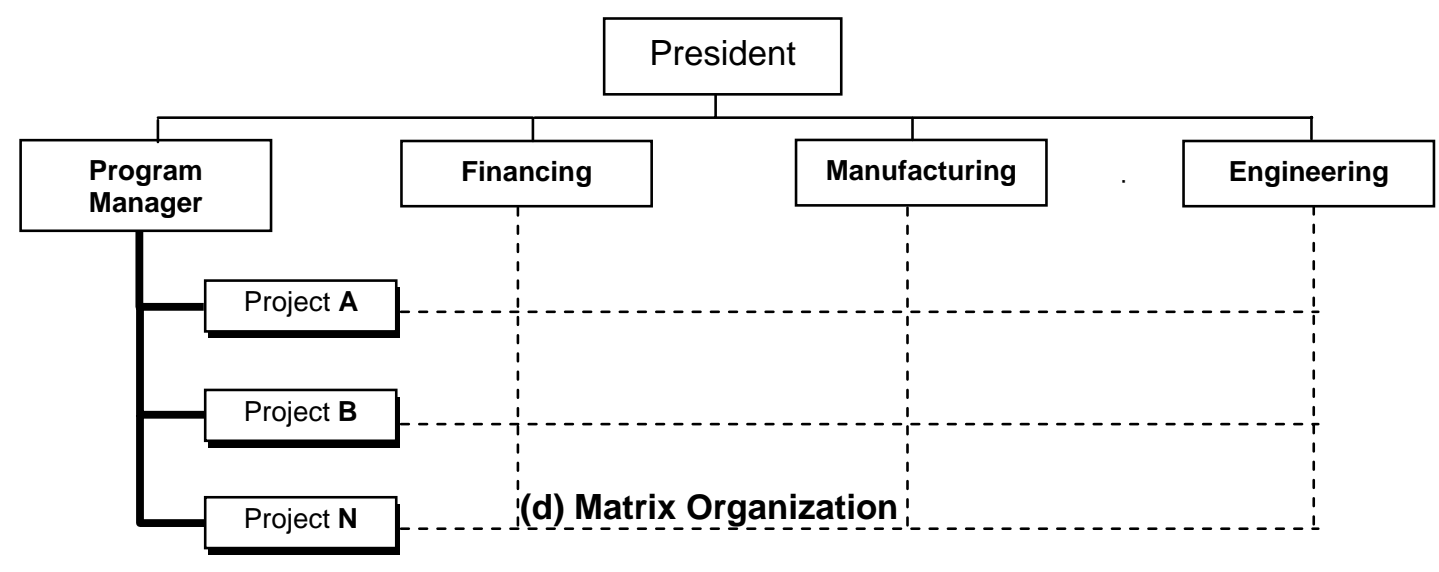

Fig. 1.13: Common Forms of Organization Structure 


\subsection{Emerging Trends}

In North America, $85 \%$ of the total construction expenditures are typically spent on new projects while the remaining $15 \%$ are spent on repair and rehabilitation. In recent years, however, a larger portion of all construction work has been shifting from new to reconstruction projects. With a currently aging infrastructure, the market for rehabilitation and renewal has been growing in North America. On the other hand, the market for new construction has been growing internationally as various developing countries around the world, particularly in Asia, Africa, and South America are in need of a lot of new infrastructure projects. It is, therefore, expected that with the whole world being converted into a one large village, success in competing at the international level is not expected to be easy and requires adaptation of the firm's management practices to new, possibly risky, environments. Contractors need not only to use efficient tools to improve the productivity of their resources, but also to consider the cultural and political environments associated with projects.

In terms of contract management, various growing trends that have evolved over the last decade are:

- Growing Design/Build;

- Growing BOT (includes financing);

- $\quad$ Project Partnering (PPP and Privatization options);

- Mergers between contractors and engineering firms;

- Internet use: send invitations to bidders, quotation or qualification requests, linking site to head office; and

- Innovative contract practices:

- $\quad$ A + B bidding method for cost and time;

- $\quad$ Lane Rental for high way construction; and

- Incentive/Disincentive clauses for contractors.

\subsection{Bibliography}

1. Halpin, D., and Woodhead, R. (1998) Construction Management. John Wiley \& Sons. $2^{\text {nd }}$ Edition.

2. PMI Standards Committee (1996) A Guide to the Project Management Body of Knowledge (pmbok guide). PMI.

3. Tenah, K. and Guevara, T. (1985) Fundamentals of Construction Management and Organization. Reston Publishing Co., Inc.

4. Nunnally, S.W. "Construction Methods and Management," Third Edition, Prentice Hall, 1993.

5. Hendrickson, C. and Au, T. "Project management for Construction: Fundamental Concepts for Owners, Engineers, Architects, and Builders," Prentice Hall, New Jersey, 1989.

6. Clough, R.H. and Sears, E. "Construction Project Management," $2^{\text {nd }}$ Edition, John Wiley \& Sons, Toronto, 1979.

7. Goldsmith, I. "Canadian Building Contracts," 2nd Edition, the Carswell Comp. Ltd., Toronto, Canada, 1976.

8. Thierauf, R.J., \& Rrosse, R.A. "Decision making Through Operations Research," John Wiley \& Sons, 1970.

9. Kerzner, H. (2000). Applied Project Mangement. . John Wiley \& Sons.

10. Kerridge, A.E. and Vervalin, C.H. (Eds) "Engineering and Construction Project Management" Gulf Publ. Co., Houston, 1986.

11. Roman, D.D., "Managing Projects: A Systems Approach" Elsevier Science Publ. Co., Inc., N.Y., 1986.

12. Oxley, R., and Poskitt, J., "Management Techniques Applied to Construction Industry" 3rd edition, Granada Publ. Ltd., Rexdale, Ontario, Canada, 1986.

13. Fisk, E. (1992) Construction Project Administration. Prentice Hall Inc. New Jersey, USA.

14. Gould, Frederick and Joyce, Nancy (1999) Construction Project Management. Prentice Hall Inc. NJ, USA.

15. Teplitz, C. and Worley, C. (1992) Project Managers are Gaining Power Within Matrix Organizations, PmNetwork, PMI, Vol. 3, No.2, pp. 33-35.

16. Cook, L. and Hancher, D. (1990) Partenering: Contracting for the Future, Journal of Management in Engineering, ASCE, Vol. 6, No. 4, pp. 431-446.

17. Cartey, G. (1995) Construction, Journal of Construction Engineering and Management, ASCE, 121(3), 319-328.

18. Herbsman, Z. (1995) A+B Bidding Method-Hidden Success Story for Highway Construction, Journal of Construction Engineering and Management, ASCE, Vol. 121, No. 4, pp. 430-437.

19. Jaraiedi, M., Plummer, R., and Aber, M. (1995) Incentive/Disincentive Guidelines for Highway Construction Contracts, Journal of Construction Engineering and Management, ASCE, Vol. 121, No. 1, pp. 112-120.

20. Harris, F., and Srinivasan, R. (1991) Lane Rental Contracting, Journal of Construction Engineering and Economics, Vol. 9, E. \& F.N. Spon Ltd., pp. 151-155.

21. Tiong, R. (1990) Comparative Study of BOT Projects, Journal of Management in Engineering, ASCE, Vol. 6, No. 1 , pp. 107-122.

22. Konchar, M., and Sanvido, V. (1998) Comparison of U.S. Project Delivery Systems, Journal of Construction Engineering and Management, ASCE, Vol. 124, No. 6, pp. 435-444. 


\section{CHAPTER 2: INFORMATION MANAGEMENT TOOLS}

From studying this chapter, you will be able to:

- Manage your company's information using Excel data management tools

- Understand the simple and powerful spreadsheet functions for managing information

- Use Excel pivot tables for summarizing and reporting data

- Use Excel mathematical optimization tool, the Solver program

- Use other add-in programs for optimization based on genetic algorithms

- Experiment with the Microsoft Project and Primavera P3 software

\subsection{Introduction}

The construction process is heavily information-dependent. A well-maintained and organized data is crucial to support the timely and cost effective planning, bidding, and control of projects. With the large amount of information related to resources and operations, it is sometimes difficult to obtain and organize such information due either to the limited time available or to the inefficient methods of data collection and organization. Thus, improving the quality, integrity, and timeliness of construction data is a well-recognized need. This chapter, therefore, introduces the basic tools that can be used to management construction data. Special emphasis is made on spreadsheet programs as a simple-to-use tool that is customary to almost all construction practitioners and also has all the power functions that satisfy the need of construction applications. Some of the database capabilities in Excel are presented in addition to some add-in programs that provide optimization capabilities. Two project management software (Microsoft Project and Primavera P3) are then introduced before being used in the various chapters of this book.

\subsection{Excel Data Management Tools}

Spreadsheets are among the earliest software innovations that had profound effect on the widespread use of personal computers. Among their strong features are their intuitive cell-based structure and the simple interface that is easy to use even for fist time user. Underneath the structure and the interface is a host of powerful and versatile features, from data entry and manipulation to a large number of functions, charts, and word processing capabilities. Newer spreadsheet versions have also added many productivity features for Internet connectivity, workgroup sharing, programmability options, and a number of add-in programs. With their wide use, spreadsheets, have been proven suitable as a tool for developing computer models in domain such as construction, for which ease of use, versatility, and productivity are main issues.

Since the core of any management system, such as the one we intend to develop for construction, is a storage of the data and information for management operations, a brief review of the database capabilities in spreadsheet programs is presented. Few basic, but infrequently used, spreadsheet features need to be known and can be used to develop practical and powerful models for construction applications: Data lists; Data Menu options; Basic spreadsheet functions such as "Vlookup"; and Pivot table reports.

Note: In Excel, a data list is the basic structure of columns and rows that contain data. The list works as a database that can be managed easily using built-in functions. It is basically a table of data in which the rows are data records and the columns are data fields, headed by field names. The characteristics of a data list are:

- Its top row is termed a header row, consisting of one or more column labels.

- All rows in the list below the header row contain records. The records are values that describe various items.

The data list figure shows an example of an estimate sheet with each row represent one item in the estimate and its quantity of work, unit, cost, etc shown in the various columns. Once the list is formed, the data management tools provided under Excel's "Data" menu, such as "Sort", "Filter", and "Ouutline" can be directly used to manage the data in these lists. The data list, a s such, becomes an intuitive and simple way of storing data related to each other. A separate list can thus be used to store separate data. One list for example can be used to store labor categories; and another list can be used to store equipment categories, and so on. Later we can learn how to link all these separate data lists to use all their data together. 

Note: The software tools used in this book are Excel and Microsoft Project. While vendors may introduce newer versions from time to time, the features used in this book are mostly standard and comparable features, if not identical, will be available in any updates. Most of these features are also available in other software products. The reader can consult with the Help system of his software to search for desired features.

\subsubsection{Sorting Lists}

\begin{tabular}{|c|c|c|c|c|c|c|c|c|c|c|}
\hline \multirow{11}{*}{$\begin{array}{l}\text { One row of } \\
\text { data headings }\end{array}$} & & A & B & $\mathrm{C}$ & D & E & $\mathrm{F}$ & G & $\mathrm{H}$ & $\bar{\Delta}$ \\
\hline & 1 & Item & Desciription & WBS & Quantity & Unit & Unit Cost & Total & & \\
\hline & 2 & Item1 & Layout & Layout & 1.00 & day & 613.67 & 614 & & \\
\hline & 3 & Item2 & Excavate Foundation \& Utility Trench & Excavation & 379.00 & $\mathrm{~m} 3$ & 3.10 & 1,175 & & \\
\hline & 4 & Item3 & Backill Utility Trench & Backill & 26.00 & $\mathrm{~m} 3$ & 1.22 & 32 & & \\
\hline & 5 & Item4 & Compact Utility Trench & Compaction & 26.00 & $\mathrm{~m} 3$ & 0.61 & 16 & & \\
\hline & 6 & Item5 & Install Weeping Tile & Backill & 52.00 & $\mathrm{~m}$ & 4.60 & 239 & & \\
\hline & 7 & Item6 & Place Granular & Backill & 4.90 & $\mathrm{~m} 3$ & 41.66 & 204 & & \\
\hline & 8 & Item? & Backill Around Foundation & Backill & 88.00 & m3 & 1.22 & 107 & & \\
\hline & 9 & Item8 & Compact Around Foundation & Compaction & 88.00 & $\mathrm{~m} 3$ & 0.61 & 54 & & \\
\hline & 10 & Itemg & Lot Grading & Excavation & 266.00 & $\mathrm{~m} 3$ & 1.22 & 324 & & \\
\hline & 11 & Item10 & Forms, Footing & Formwork & 30.40 & $\mathrm{~m} 2$ & 58.28 & 1,772 & & \\
\hline Data arranged & 12 & Item11 & Removal of Form, Footing & Formwork & 30.40 & $\mathrm{~m} 2$ & 2.91 & 88 & & \\
\hline with each & 13 & Item12 & Keyway, $50 \mathrm{~mm} \times 100 \mathrm{~mm}$ & Formwork & 76.00 & $\mathrm{~m}$ & 2.82 & 215 & & \\
\hline & 14 & Item13 & Placing Concrete, Direct Chute & Concrete & 6.10 & $\mathrm{~m} 3$ & 113.19 & 690 & & \\
\hline & 15 & Item14 & Forms, Walls & Formwork & 266.70 & $\mathrm{~m} 2$ & 78.76 & 21,006 & & \\
\hline row & 16 & Item15 & Removal of Form, Walls & Formwork & 266.70 & $\mathrm{~m} 2$ & 2.91 & 775 & & \\
\hline & 17 & Item16 & Anchor Bolts, $12 \mathrm{~mm}$ diameter & Formwork & 65.00 & ea & 9.65 & 627 & & \\
\hline & 18 & Item17 & Reinforcing, Light, Footing & Reinforcing & 0.08 & ton & $8,869.57$ & 710 & & \\
\hline ile & 19 & Item18 & Reinforcing, Light, Walls & Reinforcing & 0.19 & $\tan$ & $8,869.57$ & 1,685 & & \\
\hline & 20 & Item19 & Placing Concrete, Walls & Concrete & 26.67 & $\mathrm{~m} 3$ & 148.73 & 3,967 & & \\
\hline r2.xls" & 21 & Item20 & Bank Run Gravel, Floor:200mm deep & Backill & 31.00 & $\mathrm{~m} 3$ & 6.13 & 190 & & \\
\hline ll & 22 & Item21 & End Forms & Formwork & 76.20 & $\mathrm{~m}$ & 10.50 & 800 & & \\
\hline & 23 & Item22 & Polyethylene Vapor Barrier & Insulation & 154.00 & $\mathrm{~m} 2$ & 1.09 & 168 & & \\
\hline ts & 24 & Item23 & Placing Concrete, Floor & Concrete & 11.50 & $\mathrm{~m} 3$ & 110.54 & 1,271 & & \\
\hline in & 25 & Item24 & Steel Trowel Finish & Reinforcing & 154.00 & $\mathrm{~m} 2$ & 0.27 & 42 & & \\
\hline & 26 & Item25 & Damp Proofing, Foundation & Insulation & 107.00 & $\mathrm{~m} 2$ & 5.43 & 581 & & \\
\hline & 27. & tem26 & Insulation of Foundation & Insulation & 58.00 & $\mathrm{~m} 2$ & 27.21 & 1,578 & & \\
\hline
\end{tabular}

\section{Excel Data List (Database)}

Sorting is a valuable way of managing the data in an Excel data list. It helps you bring similar records together, for visual inspection or other purposes such as preparing reports and charting the data. You can arrange the list's data in an order that you choose by sorting the records. Suppose you have the estimate data shown above. You want to view the data arranged according to the total cost. To do so, use the data sort as shown.

\subsubsection{Filtering Lists}

Filtering the data in a worksheet list is a useful way to view a subset of the records that compose a list. To filter a list is to extract records from it, based on criteria that you set. There are two menu commands to filter a list, both found in the Filter menu that cascades from the Data menu: AutoFilter and Advanced Filter.

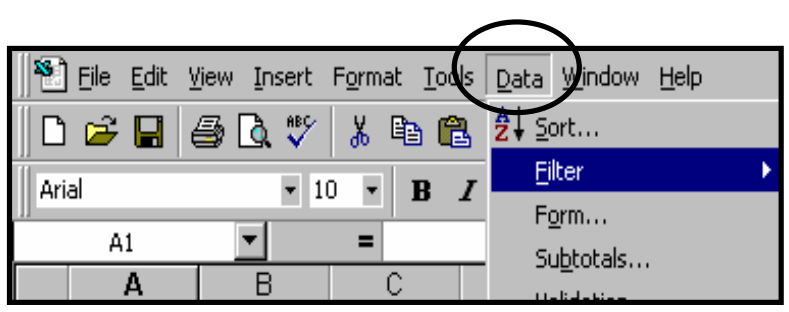

While any cell inside the data list is selected, choose the Data-Filter-AutoFilter menu option. The AutoFilter puts arrows (called AutoFilter control) beside the column labels in the header row to display filtering criteria. Notice in this figure, the drop-down box that appears when you click the control on cell B1, which contains several options in order to define the filtering criteria.

\section{Custom AutoFilter}

You can also use the Custom option in AutoFilter if you have no more than two criteria to apply. These criteria can be treated as connected by an AND or by an OR (a record is displayed if it meets either criterion). 


\section{Applying Advanced Filter}

The Advanced Filter command gives you more options than the AutoFilter command. When you choose the Data-Filter-Advanced Filter menu option to activate it. The Advanced Filter allows you to create more complicated criteria than does the AutoFilter. In particular, you can use the Advanced Filter to specify:

- $\quad$ More than two criteria, which is the limit of the AutoFilter;

- Computed criteria: For example, "Display only those records whose total cost value is greater than the average total cost value." This is termed a computed criterion because Excel must compute, in this case, the average total cost in order to determine whether a record meets the criterion.

- Consult Excel help or the appropriate figure in the "Chapter2.xIs" file.

\subsubsection{Using Data Forms}

Eentering data into the spreadsheet's native row-and-column grid is extremely tedious and prone to error. The dataform available within Excel provides a solid way for you to enter, view, and filter data. The figure shows one such form, which was generated for the estimate data list behind the form. Using this built-in form, we can edit or delete the existing records in the list or add new records. You can activate the form from any point in the list using the DataForm menu option.

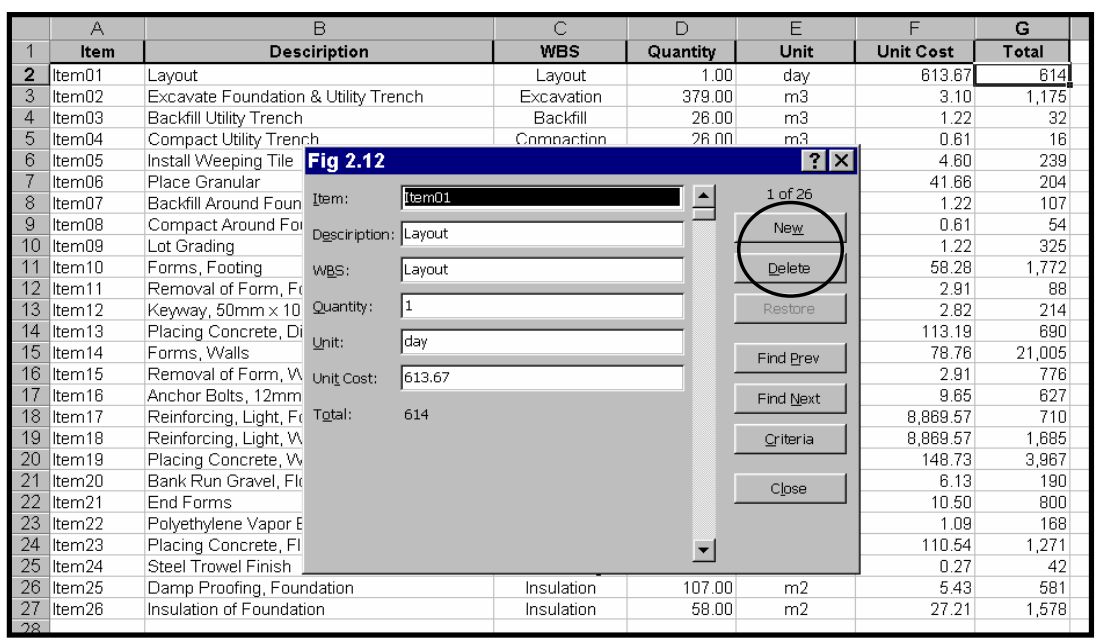

\subsection{Useful Excel Functions for Retrieving List Information}

Getting data out of a list in a clear and efficient manner is an important part of the data-management process. Excel has several tools that help you accomplish that task. The Advanced Filter dialog box has already been introduced, having an option to copy records that match the criteria you specify to another part of the sheet, where you can manipulate them without affecting the original list.

In addition to extracting selected data from a list, you can create formulas that return specific information from the list. The built-in STATISTICAL LIST FUNCTIONS calculate statistics for only the records in the list that meet the criteria that you specify. The LOOKUP FUNCTIONS help you manage large lists of reference data by returning information for specific records from specific fields. The MATCH and INDEX functions give you further control over the data by allowing you to identify a given entry's position in a list or an array. The OFFSET function extends the capabilities of Index function by reaching into a worksheet range and returning any number of values from that range.

\subsubsection{Statistical List Functions}

Excel's statistical list functions, sometimes referred to as the "D" functions (Database Functions), provide an instantaneous way to measure a number of important list statistics, such as sums, averages, and standard deviations.

As shown, the most commonly used statistical list function, DSUM formula in cell $\mathrm{H} 2$ uses the criterion

\begin{tabular}{|c|c|c|c|c|c|c|c|c|}
\hline \multicolumn{2}{|r|}{$\mathrm{H} 2$} & \multicolumn{3}{|c|}{ = =DSUM(A1:E19,"Project Value",A21:E22) } & & \multirow[b]{2}{*}{$\mathrm{F}$} & \multirow[b]{2}{*}{ G } & \multirow[b]{2}{*}{$\mathrm{H}$} \\
\hline & A & B & C & D & $E$ & & & \\
\hline 1 & Project Code & Region & Project Type & Project Manager & Project Value & & & \\
\hline 2 & $\mathrm{C}-01$ & Central & Residential & Bill & 200,000 & & DSUM : & $2,310,000$ \\
\hline 3 & W-03 & West & Residential & Thomas & 170,000 & & & \\
\hline 4 & C-03 & Central & Residential & Smith & 325,000 & & & \\
\hline 5 & $\mathrm{E}-05$ & East & Office Building & Smith & 145,000 & & & \\
\hline 6 & C-05 & Central & Restaurant & Smith & 180,000 & & & \\
\hline 7 & C-06 & Central & Office Building & Green & 420,000 & & & \\
\hline 8 & $C-07$ & Central & Office Building & Jones & 600,000 & & & \\
\hline 9 & $E-01$ & East & Residential & Thomas & 185,000 & & & \\
\hline 10 & $\mathrm{E}-02$ & East & Residential & Thomas & 210,000 & & & \\
\hline 11 & $\mathrm{C}-02$ & Central & Residential & Bill & 225,000 & & & \\
\hline 12 & $E-03$ & East & Office Building & Bill & 160,000 & & & \\
\hline 13 & E-04 & East & Office Building & Jones & 210,000 & & & \\
\hline 14 & W-01 & West & Residential & Green & 210,000 & & & \\
\hline 15 & C-04 & Central & Residential & Smith & 360,000 & & & \\
\hline 16 & W-02 & West & Office Building & Green & 300,000 & & & \\
\hline 17 & $E-06$ & East & Restaurant & Davis & 225,000 & & & \\
\hline 18 & W-04 & West & Office Building & Jones & 380,000 & & & \\
\hline 19 & W-05 & West & Restaurant & Davis & 140,000 & & & \\
\hline 20 & & & & & & & & \\
\hline 21 & Project Code & Region & Project Type & Project Manager & Project Value & & & \\
\hline 22 & & Central & & & & & & \\
\hline 23 & & & & & & & & \\
\hline
\end{tabular}


range A21: E22 to calculate the total project value in the Central Region.

The syntax of the DSUM function is =DSUM(list range, calculation field, criteria range)

Because these functions use criteria ranges, you can specify that the calculation includes only certain records from the list by entering the appropriate criteria. This structure allows you to make the same formula quickly yield statistics for a number of different sets of records simply by changing the criteria in the criteria range. For example, if you entered the criterion "west" in cell B22, the DSUM formula would immediately reflect the total project value in the West Region.

The table below includes a list of Excel's statistical functions that deal with data lists. Each of these functions has the same syntax as the DSUM formula in cell H2, each uses the same list, field, and criteria arguments.

Statistical List Functions

\begin{tabular}{l|l}
\hline Function & Returns \\
\hline DAVERAGE & Average \\
DCOUNT & Count of cells containing numbers \\
DCOUNTA & Count of nonblank cells \\
DMAX & Maximum \\
DMIN & Minimum \\
DPRODUCT & Product \\
DSTDEV & Standard deviation \\
DSRDEVP & Population standard deviation \\
DSUM & Sum \\
DVAR & Variance \\
DVARP & Population variance \\
\hline
\end{tabular}

You can use these statistical functions to interpret list data and spot potential problems such as data-entry errors. You can check maximum and minimum values; compare maximum and minimum values to average; and compare the population standard deviation and population variance for different criteria.

\subsubsection{Looking up Data}

Referencing and searching a list is another important part of the data management process. In realistic systems, where several lists of data are available, a link needs to be established among them (similar to the relational database concept). One simple and important spreadsheet function "Vlookup" can be used to link separate lists of information by making a reference to where the original data is.

\section{a) VLOOKUP Function:}

b) Using the MATCH Function to Aid Lookups:

c) LOOKUP Function:

d) INDEX Function:

e) OFFSET Function:

\subsection{Excel Reporting Features: Pivot Tables}

Reporting is another essential requirement for obtaining summary data on resources and operations. In Excel, the pivot table wizard provides automated \& powerful reports. Pivot tables enable you to:

\begin{tabular}{|c|c|c|c|c|c|}
\hline & A & $B$ & C & D & $E$ \\
\hline 1 & Region & Project Type & Year & Project Value & \\
\hline 2 & East & Residential & 1999 & $\$ 185,000$ & \\
\hline 3 & West & Residential & 1998 & $\$ 215,000$ & \\
\hline 4 & East & Residential & 1998 & $\$ 210,000$ & \\
\hline 5 & East & Office Building & 1999 & $\$ 160,000$ & \\
\hline 6 & West & Office Building & 1998 & $\$ 240,000$ & \\
\hline 7 & East & Office Building & 1998 & $\$ 245,000$ & \\
\hline 8 & West & Residential & 1999 & $\$ 165,000$ & \\
\hline 9 & & & & & \\
\hline 10 & & & & & \\
\hline 11 & & & & & \\
\hline 12 & Sum of Project Value & & Project Type & & \\
\hline 13 & Year & Region & Office Building & Residential & Grand Total \\
\hline 14 & \multirow[t]{2}{*}{1998} & East & $\$ 245,000$ & $\$ 210,000$ & $\$ 455,000$ \\
\hline 15 & & West & $\$ 240,000$ & $\$ 215,000$ & $\$ 455,000$ \\
\hline 16 & \multicolumn{2}{|l|}{1998 Total } & $\$ 485,000$ & $\$ 425,000$ & $\$ 910,000$ \\
\hline 17 & \multirow[t]{2}{*}{1999} & East & $\$ 160,000$ & $\$ 185,000$ & $\$ 345,000$ \\
\hline 18 & & West & & $\$ 165,000$ & $\$ 165,000$ \\
\hline 19 & \multicolumn{2}{|l|}{1999 Total } & $\$ 160,000$ & $\$ 350,000$ & $\$ 510,000$ \\
\hline 20 & \multicolumn{2}{|l|}{ Grand Total } & $\$ 645,000$ & $\$ 775,000$ & $\$ 1,420,000$ \\
\hline 21 & & & & & \\
\hline
\end{tabular}


- summarize long lists in a compact format;

- $\quad$ find relationships within lists that are hidden by all details;

- $\quad$ see differences in one variable that are associated with differences in another variable; and

- display data in the form of subtotals, averages, percentages, standard deviations, and so on.

\section{Using the Pivot Table Wizard to Create a Report}

There are two main ways to start the wizard; either by selecting Pivot Table Wizard from the Data menu or by using the Pivot Table Wizard toolbar button.

\subsection{Excel Optimization Tools}

Operations research tools such as linear/non-linear programming are quantitative methods that can be used to enhance decision-making and foster effectiveness in the management of projects. Such techniques are beneficial because:

- $\quad$ They are applicable to a large variety of practical problems.

- Many software systems like Excel are available inexpensively and have these capabilities built-in.

- These tools can be effectively applied, hiding all the underlying complexities of the theory and mathematical computations.

\subsubsection{Goal-Seek}

This Excel feature can be used to determine the proper values for the variables in any application so that a goal is met.

\subsubsection{Excel Solver for Mathematical Optimization}

Goal-Seek, as explained is a simple tool, which can be used to solve problems that involve one variable and that involve no constraints on the solution. Another Excel tool, Solver, which is an add-in program for general linear and nonlinear integer programming, is very useful for solving multivariable optimization problems. It uses the Simplex and branch-and-bound mathematical techniques for the optimization.

If Solver is not found under the Tools menu, select Tools, Add-Ins, and install Solver. Then look for the file "Solvsamp.xls" in your system, which has several interesting applications of the Solver program.

Using Solver to formulate optimization problems is a simple and straightforward process. Optimization, in general, tries to maximize or minimize an objective function (a goal) by determining the optimum values (quantities) for a set of decision variables so as to meet certain constraints. Using Solver, the user needs to establish the calculations sheet and then simply defining the cells that represent the objective function, the variables, and the constraints.

Example: This example involves the shipment of aggregates from three quarries to five projects. The aggregates can be shipped from any plant to any project, but it obviously costs more to ship over long distances than over short distances. The problem is to determine the amounts to ship from each quarry to each project at minimum shipping cost in order to meet the demand, while not exceeding the supply limit.

Data:

- The three quarries A, B and C can produce a maximum of 310, 260 and 280 truckloads per day, respectively.

- The five projects PR1, PR2, PR3, PR4, and PR5 have daily demands of 180, 80, 200, 160 and 220 truckloads, respectively.

- $\quad$ The shipping costs (\$) from any quarry to any project.

\section{Solution:}

The solution has to follow the four steps of the systematic approach described before: 
1. Variables are represented in separate cells (C4: G6) with initial values of $1 \mathrm{~s}$. The variables represent the amount to be shipped from each quarry to each project;

2. Each data element is represented in a separate cell. These include the maximum supply of each quarry (H4:H6); demand amount of each project (C8: G8); and shipping costs (C12: G14);

3. Worksheet formulas written to perform intermediate calculations. This

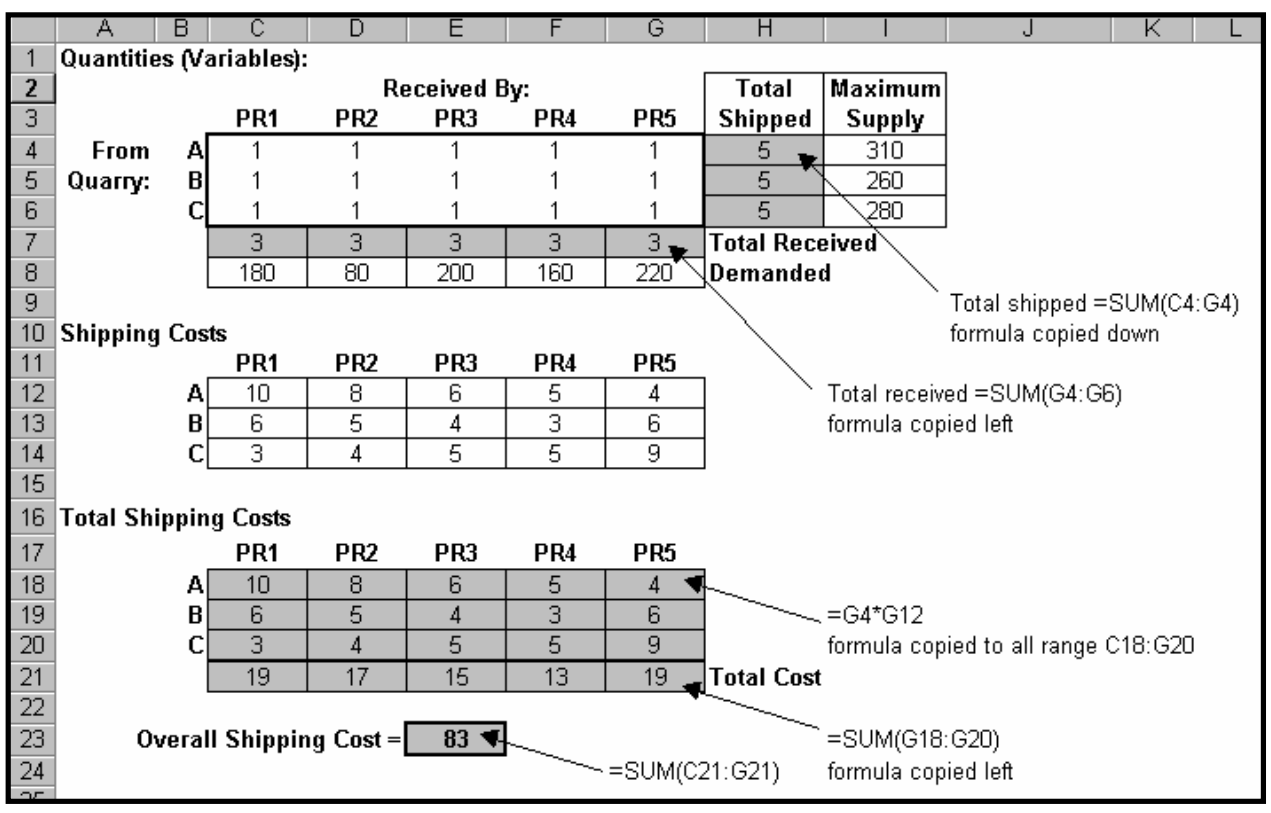
includes actual amount delivered to each project, actual amount shipped from each quarry, and the associated shipping cost; and

4. Formulate a single cell for the Goal or objective function, in our example, the sum of overall shipping costs (cell E23).

\section{Optimization Model}

To verify the spreadsheet model, any change in the values of the variables should result in appropriated changes in the objective function.

The Solver program can then be activated from the Tools menu and the optimization parameters can be set as shown. The optimization objective is to minimize the total shipping cost (cell E23). The optimization variables are the quantities in the range C4: G6. The optimization constraints were also set to limit the values of the variables to positive integers, not to exceed the maximum available truckloads per day, and to meet the demand for each project. Using Solver, a solution was reached, achieving a minimum total shipping cost of $\$ 3,200$, as shown.

\section{Solver Solution}

The variables take their optimum values that result in lowest shipping cost.

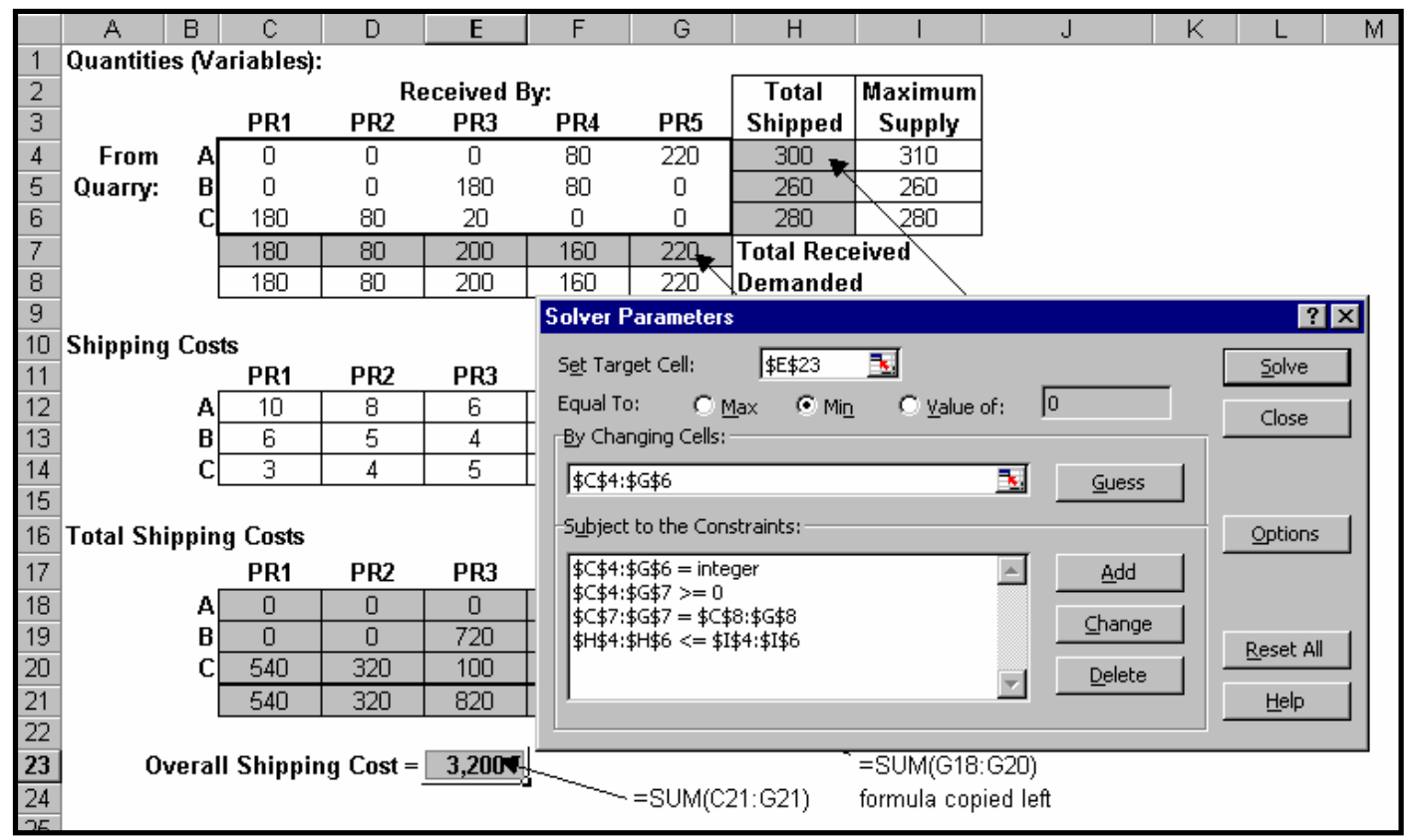




\subsubsection{Non-Traditional Optimization Tools}

While Solver is a convenient tool for mathematical optimization, in some situations it can get stuck and fails to solve the problem or gets trapped in local optimum. Alternatively, new software programs have recently been introduced as a result of advancements in the artificial intelligence branch of computer science. For optimization applications, a new technique, called Genetic Algorithms (GAs) has recently emerged with random optimization capabilities inspired by the biological systems' improved fitness through evolution. Usually, the process is continued for a large number of cycles until a near-optimum solution is arrived at.

One well known software for GA-based optimization is the Evolver software from Palisade Inc. More information on the two programs can be found on their web sites. This software, and others that you may find through a web search, works as an add-on to Excel, is very user friendly, and is nicely integrated into the Excel environment. Usually most of the Genetic Algorithm software provide you with an interface that is much similar to the Excel Solver. You need to select the cells that represent the objective function, variables and constraints, and can be identical to those that you specify for the Excel Solver.

\subsection{Project Management Software}

Proper planning and scheduling, as integral parts of this book, are key factors to the completion of a construction project within budget, on time, and with few problems. Along the course of this book, we'll be using one of the common software systems that support project management functions, Microsoft Project 98 and Primavera P3. Evaluation versions of both software systems are available from their web sites (see Appencix II). Basically, Microsoft Project is a popular easy-to-use project management software and P3 is a high-end software for project management. Both software allow you to put together a project plan, organize resources, assign responsibilities, and follow up during construction.

Both software, and any other project management software, cannot guarantee a successful project plan but they are invaluable planning tool for:

- Organizing the plan and thinking through the details of what must be done,

- Scheduling deadlines that must be met,

- $\quad$ Scheduling the tasks in the appropriate sequence,

- Assigning resources and costs to tasks and scheduling tasks around resource availability,

- Fine-tuning the plan to satisfy time and budget constraints or to accommodate changes, and

- Preparing professional-looking reports to explain the project to owners, top management, supervisors, workers, subcontractors, and the public.

Once work begins on the project, you can use the project management software to:

- $\quad$ Track progress and analyze the evolving "real" schedule to see if it looks like you will finish on time and within budget,

- Revise the schedule to accommodate changes and unforeseen circumstances,

- $\quad$ Try out different what-if scenarios before modifying the plan,

- Communicate with team members about changes in the schedule (even automatically notify those who are affected by changes!) and solicit feedback about their progress,

- Post automatically updated progress reports on an Internet Web site or a company intranet, and

- Produce final reports on the success of the project and evaluate problem areas for consideration in future projects.

\subsection{Summary}

In this chapter, spreadsheets have been presented as an ideal platform with diverse tools that can be used for creating comprehensive models in construction. Many of the simple yet powerful features of Excel have been introduced, in addition to some add-in programs for optimization capabilities. In addition to Excel, one of the commonly used software for project management, Microsoft Project, has been briefly introduced so that both tools can be used in the remaining chapters of this book. 